\title{
La mirada (masculina) que insiste: imágenes y género en un álbum de fotos de la historia argentina
}

\section{Sergio Caggiano}

Universidad Nacional de La Plata

E-mail: sergio.caggiano@gmail.com 


\section{Resumo}

Com quais representações visuais imaginamos a "comunidade nacional"? Neste artigo, procuro realizar uma análise das fotografias dos quatro tomos do álbum La fotografía en la Historia Argentina, entregue gratuitamente pelo jornal Clarín em 2005. Tento interpretar as presenças e as ausências, as modalidades de representação e os critérios de classificação social. Com maior precisão, procuro estudar as associações fixas das imagens dos homens e das mulheres com determinadas situações, contextos e ações que parecem definir e cristalizar, nessa fixidez, os "seus" lugares respectivos na sociedade. A divisão entre o público e o privado, e as valorações diferenciais desses espaços comparecem (de novo) como eixos centrais para a interpretação das fotografias.

Palavras-chave: sexismo; visibilização/ invisibilização; sistemas de classificação social.
Abstract

Which are the images that we use to imagine the "national community"? In the second half of 2005 Clarin, the newspaper of major circulation in Argentina, delivered for free a photograph book defined as an "album of the argentine history". This essay analyzes that book, seeking to understand modalities and criteria of providing visibility and of social classification. More precisely, it reflects upon the representation of women and men in the album, on the forms in which these women and men are showed and on the ways in which they disappear; finally, it reflects upon the visual construction of "their" places at society. Divisions between public and private and unequal valuations about these social spaces appear (again) as the keys to interpret these photographs.

Keywords: sexism; visibilization/ invisibilization; systems of social classification.

ILHA

volume 10 - número 2 
La mirada (masculina) que insiste: imágenes y género en un álbum de fotos de la...

$\mathrm{D}$ esde diversas disciplinas y enfoques, se ha tematizado en las últimas décadas la relación entre modos de la mirada, representaciones visuales y ejercicio de poder (Foucault, 1989; Berger, 1972) así como, más precisamente, el lugar social de la fotografía en las estrategias de distinción social (Bourdieu, 1989) y en los procesos de producción y reproducción de diferencias y desigualdades (Smith, 1999). Dentro de este conjunto general de inquietudes, puede colocarse la pregunta particular acerca de la construcción de "mundos de imágenes" (Poole, 2000) que se sostienen en (y son sostén de) una forma determinada de relaciones de género. ¿Con qué representaciones visuales concretas imaginamos la comunidad nacional (Anderson, 1993)?, ¿qué lugares ocupan en esta imaginación las mujeres y qué lugares los hombres?

Siguiendo a Elizabeth Edwards, la fotografía puede entenderse como "[...] una metáfora del poder, teniendo la capacidad de descontextualizar y apropiarse del tiempo y del espacio y de aquellos que existen dentro de él [...]. Ella puede volver lo invisible visible, lo desapercibido percibido" (Edwards, 1996, p. 16, mi traducción). También define a la fotografía como metáfora del poder su capacidad inversa y complementaria: hacer invisible lo visible y lo percibido desapercibido. Asimismo, la confección de colecciones, archivos, muestras, selecciones de fotografías potencia dichas capacidades de visibilización e invisibilización, de manera decisiva, por lo demás, si tal confección está a cargo de un gran multimedia.

Durante la segunda mitad de 2005, en sucesivas semanas el diario Clarín ${ }^{1}$ entregó gratuitamente con su edición dominical los cuatro tomos que conforman La fotografía en la Historia Argentina. El libro

ILHA

volume 10 - número 2 
completo cuenta con 575 páginas y recoge cerca de 500 imágenes organizadas en diez capítulos ${ }^{2}$. De acuerdo con una nota introductoria del editor general del periódico, “[...] (e)ste libro es un álbum de la historia argentina [...]. Es un documento múltiple que refleja los distintos rostros de la historia" ${ }^{\prime \prime}$. El objetivo que me propongo en este artículo es, precisamente, el de interrogar y problematizar la tal multiplicidad de rostros que esta historia reflejaría.

En las páginas que siguen, intento analizar el álbum buscando dar cuenta de presencias y de ausencias (junto a esas presencias y dentro de ellas), de las modalidades de representación de quienes han participado de aquella historia, de los criterios de visibilización y de clasificación social, de las asociaciones fijas entre determinados tipos de personas y determinadas situaciones, contextos y acciones que parecen definir y cristalizar, por esa fijeza, "su" lugar en "la sociedad". ¿Qué espacios y qué modos de aparición (y desaparición) les son reservados a hombres y mujeres en esta "Historia Argentina"?, ¿qué mujeres, qué hombres y qué relaciones entre ellos se nos muestran?, ¿qué distribución de prácticas, valores, esferas de acción es propuesta como "normal" (es decir, como común y corriente y como adecuada a una norma)?

Para responder a mis interrogantes, seguiré tres vías principales. Por un lado, haré algunas observaciones acerca de las diferencias cuantitativas de la representación de unos/as y de otros/as en esta selección de fotografías. Por otro lado, ofreceré descripciones de algunas de las fotografías, más o menos detalladas según los casos, e hipótesis interpretativas a partir de dichas descripciones. En tercer lugar, se tornará relevante en ocasiones analizar las relaciones entre las imágenes y los textos escritos (epígrafes o inscripciones) que las acompañan y que pretenden estabilizar o controlar la peculiar apertura semiótica del "mensaje visual" (Barthes, 1992; Santaella y Nöth, 1996). El libro de Clarín se divide, como señalé, en cuatro tomos. El primero abarca desde "los orígenes" hasta finales del siglo XIX, el segundo desde entonces hasta 1945, el siguiente llega a 1976, y el cuarto y último hasta el año 2005. La división parece no responder solamente a la cantidad y a la disponibilidad de materiales, sino

ILHA

volume 10 - número 2 
La mirada (masculina) que insiste: imágenes y género en un álbum de fotos de la...

que puede apreciarse un criterio político en su estructuración (cfr. los nombres de los capítulos en la nota ii). Me baso, en principio, en este ordenamiento propuesto por Clarín sólo a efectos de organizar el análisis y la exposición. Como se verá, los resultados no necesariamente lo confirman, pudiendo establecerse diferentes líneas de continuidad o de ruptura.

(El trabajo atiende a la totalidad de las fotografías seleccionadas por Clarín, con la excepción de las fotos de "multitudes" o grupos muy grandes, en los que se busca mostrar precisamente "la multitud" y se vuelve muy difícil hacer precisiones acerca de las imágenes de las personas que la conforman, y de las fotos que tienen como objeto diferentes espacios abiertos, edificios públicos en construcción, panorámicas urbanas, etc., aun cuando puedan aparecer en ellas pequeñas figuras humanas. Tampoco se incluyen en este trabajo las pocas imágenes de hombres y mujeres "marcados/as" étnica o racialmente: negros/as e indígenas ${ }^{4}$. En total, se han considerado para el análisis unas 330 fotografías).

\section{La mirada sexista en la asignación de tareas y espacios sociales}

Los personajes que conforman esta extensa galería que es el álbum constituyen una serie variada de la que participan presidentes de la nación, trabajadores, dirigentes políticos y sociales, militares de alto rango, miembros de instituciones civiles, soldados y milicianos, gauchos e inmigrantes, transeúntes y diversos actores de escenas de la vida urbana o rural. En esta enumeración, recurro a generalizaciones con términos masculinos de manera deliberada. No porque no haya imágenes de mujeres en el álbum, sino para advertir desde el comienzo el carácter masculino y patriarcal de la selección.

En la misma dirección, antes de atender el contenido de cada uno de los tomos, es preciso señalar un aspecto cuantitativo que constituye un denominador común a los cuatro y que resulta impactante: la gran diferencia en el número de fotografías de hombres y de mujeres a favor de los primeros. Sin pretensión de valor

ILHA

volume 10 - número 2 
estadístico, un cuadro comparativo permitirá graficar esa diferencia. El cuadro está elaborado a partir de una primera clasificación de las fotografías, que reconoce las siguientes categorías:

1) hombres solos "con nombre". Se trata de representaciones individuales de hombres que, por alguna razón, son considerados por los editores como personajes conocidos y, consecuentemente, presentados con su nombre y/o apellido en el título o el epígrafe de la foto;

2 ) hombres "con nombre" acompañados. Reúne al tipo de personajes anteriores en los casos en que se muestran acompañados de grupos de "desconocidos" o, eventualmente, a pequeños grupos de personajes igualmente famosos;

3) mujeres solas "con nombre". Es el equivalente de la primera categoría para el caso de las mujeres;

4) mujeres "con nombre" acompañadas. Es el equivalente de la categoría 2 para el caso de las mujeres;

5) hombres solos "sin nombre". Representaciones individuales de hombres que no son personajes famosos ni son identificados por su nombre;

6) mujeres solas "sin nombre". El equivalente de la categoría anterior para las mujeres;

7) grupos $^{5}$ de hombres. Conjuntos formados exclusivamente por varones sin identificación a la vista;

8) grupos de mujeres. El equivalente de la categoría anterior para las mujeres;

9) grupos mixtos. Conjuntos de hombres y mujeres sin identificación a la vista ${ }^{6}$.

ILHA

volume 10 - número 2 
La mirada (masculina) que insiste: imágenes y género en un álbum de fotos de la...

\begin{tabular}{|l|c|c|c|c|c|c|c|c|}
\hline & \multicolumn{2}{|c|}{ TOMO I } & \multicolumn{2}{c|}{ TOMO II } & \multicolumn{2}{c|}{ TOMO III } & \multicolumn{2}{c|}{ TOMO IV } \\
\hline & cant. & $\%$ & cant. & $\%$ & cant. & $\%$ & cant. & $\%$ \\
\hline 1- Hombres "con nombre" & 21 & 37,5 & 18 & 19,8 & 26 & 28,9 & 16 & 17 \\
\hline 2- Hs. c/n acompañados* & & & 14 & 15,4 & 32 & 35,6 & 35 & 37,2 \\
\hline 3- Mujeres “con nombre" & 3 & 5,4 & 3 & 3,3 & 4 & 4,4 & 4 & 4,2 \\
\hline 4- Ms. c/n acompañadas* & & & 4 & 4,4 & 7 & 7,8 & 1 & 1,1 \\
\hline 5- Hs. solos "sin nombre" & 3 & 5,4 & 1 & 1,1 & 2 & 2,2 & 1 & 1,1 \\
\hline 6- Ms. solas "sin nombre" & 2 & 3,6 & 1 & 1,1 & 2 & 2,2 & 0 & 0 \\
\hline 7- Grupos de hombres & 16 & 28,6 & 37 & 40,7 & 12 & 13,3 & 25 & 26,6 \\
\hline 8- Grupos de mujeres & 1 & 1,8 & 2 & 2,2 & 1 & 1,1 & 1 & 1,1 \\
\hline 9- Grupos mixtos & 10 & 17,8 & 11 & 12,1 & 4 & 4,4 & 11 & 11,7 \\
\hline
\end{tabular}

Cuadro 1 - Cantidades de fotografías según género

* Puede verse que estas categorías aparecen en el tomo II (y en el III y el IV, adquieren algo más de importancia). Los avances técnicos han permitido por entonces la toma instantánea (cada vez de mejor calidad y más fácil realización), y se ha extendido la actividad del reportero gráfico facilitando las fotografías de hechos y sucesos "en vivo", que permiten capturar instantes de la vida pública de alguna personalidad famosa, en actos u otras situaciones, acompañada por seguidores, público, colegas, etc.

Me interesa destacar sólo algunos de los datos presentados en este cuadro. Como dije, la cantidad de fotos de hombres es muy superior a la de fotos de mujeres. Esto se distingue mejor si observamos sumados los porcentajes correspondientes a las categorías de hombres ( solos o acompañados), por un lado, y a las de mujeres, por otro. En el primer tomo, obtenemos $71,5 \%$ para las categorías de hombres y $10,8 \%$ para las de mujeres; en el tomo II, $77 \%$ y $11 \%$; en el III, $80 \%$ y $15,5 \%$; y en el IV, $81,9 \%$ y $6,4 \%$, respectivamente. Lo que puede verificarse es una notable continuidad, y hasta puede percibirse que, de manera llamativa, la razón entre los dos términos se eleva en el último de los tomos $(6,6 ; 7 ; 5,2 ; 12,8)$, es decir que crece la diferencia en el tomo que corresponde al período más reciente. Otro aspecto interesante es la muy baja cantidad, absoluta y relativa, de imágenes de mujeres en grupos. Si comparamos entre sí sólo las categorías 7 ("grupos de hombres") y 8 ("grupos de mujeres"), la razón es incluso mayor al cociente ya presentado que resultaba de

ILHA

volume 10 - número 2 
Sergio Caggiano

relacionar entre sí todas las categorías masculinas sumadas, por un lado, y las femeninas, por otro. En este caso, obtenemos para cada uno de los tomos: 15,$9 ; 18,5 ; 12,1 ; 24,2$.

Estas diferencias numéricas son sin duda significativas, y es particularmente revelador el mantenimiento de estas diferencias a lo largo de los cuatro tomos. Al advertir la abultada disparidad en el tomo I, es razonable que especulemos que la mayor presencia masculina está determinada por la disponibilidad de los materiales fotográficos de la época. Sin embargo, la total continuidad en los porcentajes de los tomos siguientes echa por tierra esa hipótesis rápidamente. Así, no parece haber más que motivos ideológicos en un sentido amplio para que se dé tal disparidad: es un enfoque masculino y patriarcal de representación de la historia nacional lo que ocasiona la diferencia numérica. Un examen de las personas, situaciones y esferas de la vida social seleccionadas para esta representación corrobora la intervención de tal enfoque.

\section{Dónde estaban, están y deben estar los hombres y las mujeres}

Los hombres "con nombre" del tomo I conforman una inequívoca vitrina de próceres "de la patria": generales, intelectuales, presidentes. Las pocas mujeres "conocidas" son presentadas en este tomo como una sección apendicular de esta vitrina. Ellas son: Juana Sosa, Manuelita Rosas y Mariquita Sánchez de Thompson. La imagen de Juana Sosa, además del "retrato de una dama porteña", es el retrato de una "muy amiga de Manuelita Rosas", y ésta, a su vez, podría decirse que es el retrato de su padre. Como subraya el epígrafe: "Juan Manuel de Rosas no era amigo de los daguerrotipos y, por eso, no posó para ellos. Sin embargo, su hija Manuelita permaneció frente a la cámara y dio origen a uno de los primeros retratos femeninos". Por su lado, Mariquita Sánchez de Thompson fue, como nos recuerda la inscripción correspondiente, quien abrió su casa a la causa patriótica: allí habrían tenido lugar debates políticos y culturales, y se habría cantado el himno nacional argentino por primera vez.

ILHA

volume 10 - número 2 
La mirada (masculina) que insiste: imágenes y género en un álbum de fotos de la...

La representación de hombres y mujeres "desconocidos/as" retratados/as individual o grupalmente es coherente con la de los hombres y las mujeres "con nombre". Los hombres desarrollan sus trabajos en la calle o en espacios abiertos (vendedores ambulantes, pescadores, trabajadores portuarios), comparten un asado a cielo abierto, u ocupan el salón de una peluquería y barbería. Se presenta también su participación militar en los ejércitos de la "Guerra del Paraguay" o de la "Campaña al Desierto", y la actividad política de los grupos de hombres que toman las calles en las Revoluciones del 80 y del 90. Las mujeres fotografiadas hacen exclusivamente trabajo doméstico: buscan agua en un aljibe, lavan ropas en la costa del río, etc. Hombres y mujeres trabajan. Los primeros lo hacen en "la calle" (y en la calle hacen la política de las revoluciones o comparten los espacios de "publicidad" masculina de fines del siglo XIX, como las barberías), mientras que las mujeres trabajan en la casa. Las fotos de parejas o grupos mixtos hacen confluir las imágenes anteriores. Hombres venden en la calle el producto de su trabajo (carne, leche) a mujeres que compran cerca de las puertas de sus casas. Otras fotos muestran familias y parejas de novios a punto de casarse ${ }^{7}$.

El conjunto de todas estas imágenes produce una clara estructuración de espacios sociales y una igualmente clara división de género de estos espacios. Se trata de un aspecto clave en la configuración de lo público y lo privado ${ }^{8}$. Las imágenes de hombres y mujeres aparecen distribuidas de acuerdo con el eje calle/casa ${ }^{9}$. Dependiendo de la clase y la posición social, los hombres se muestran en el trabajo, en el frente de batalla, en las manifestaciones políticas, en las instituciones de gobierno. La calle misma o las extensiones abiertas son los contextos usuales de estas tomas. Las fotos de estudio o en salones cerrados siempre presentan elementos que conectan con el exterior y con la vida legislativa, administrativa o militar: la banda presidencial o el uniforme del fotografiado, un libro en sus manos, una espada. Las mujeres también difieren socialmente entre ellas, pero todas coinciden en su referencia a la privacidad del hogar. Unas se aproximan a la política apenas como representantes de un hombre (el caso de Rosas) o por ofrecer el salón de su casa a la

ILHA

volume 10 - número 2 
discusión de los hombres. Otras, como empleadas (o como esposas, madres, hijas), se encargan del trabajo doméstico. Las tomas interiores tienen a la vista las huellas de esa interioridad, como los respaldos de las sillas o las telas de los manteles que parecen continuarse en las telas de los vestidos ${ }^{10}$. De manera inversa y complementaria a lo que sucede con los varones, las fotografías de mujeres en espacios abiertos revelan signos que conectan con el interior del hogar: se ve la puerta de la casa de una mujer que compra al vendedor ambulante, las damajuanas con la que otra acarrea el agua, etc.

En este sentido, se vuelve muy significativa la foto con la que se cierra este primer tomo. Es una gran imagen nocturna titulada "Despedida del año en Avenida de Mayo (1899)", que ocupa casi dos páginas y expone una reunión de vecinos aguardando el Año Nuevo en la calle. Se aprecia una gran cantidad de personas que, ubicadas en mesas y sillas dispuestas a lo largo de la vereda, observan a la cámara, colocada a unos metros de distancia. Algunos beben o fuman. La hilera de asistentes se continúa a un lado y a otro en el "fuera de campo"; detrás de los árboles de la acera, se ven fachadas de edificios y un muro cubierto de afiches. El epígrafe apunta: "Hombres y mujeres miran hacia la lente del fotógrafo [...]. El calor no logró que las acicaladas damas y los distinguidos caballeros perdieran la compostura". Sin embargo, una mirada ligeramente atenta puede distinguir una abultada sobrerrepresentación de galeras y de sombreros, de sacos y de bigotes por sobre los vestidos y los tocados. En verdad, sólo es posible detectar a dos "acicaladas damas" entre más de cuarenta "distinguidos caballeros".

Entre los cuatro tomos de Clarín, no se hallan continuidades sólo en los aspectos cuantitativos. El tomo I es anticipatorio a propósito de la principal línea que propuse para interpretar esta historia argentina atravesada por las relaciones de género. La distribución de los espacios público y privado y su asignación "natural" a hombres y mujeres (la sugerencia de la política como terreno masculino o el predominio de las formas masculinas de entender la política, la reproducción de la desigual división sexual del trabajo, la virtual reclusión de la mujer en la casa y la calle construida como lugar de

ILHA

volume 10 - número 2 
La mirada (masculina) que insiste: imágenes y género en un álbum de fotos de la...

hombres) son, aun con diferencias y particularidades, una suerte de "núcleo duro" que se mantiene constante en la construcción de este repertorio visual de historia nacional.

En el segundo tomo (1900-1945), las fotografías de hombres "conocidos" apuntan también a los hombres fuertes de la política, aunque en este tomo hay una cierta diversificación de los campos de referencia. Las "personalidades" (masculinas) de la patria también se reclutan entre deportistas, cantantes, escritores, "hombres de ciencia". Se reproducen momentos o personajes famosos del fútbol, el boxeo o el automovilismo, el tango o las letras. Esta diversificación es posible, porque las nuevas técnicas del período permiten registrar fotográficamente mayor cantidad y variedad de situaciones de la vida social (y personal) "nacional". Además, de este modo el álbum ratifica ese momento histórico como el de conformación o consolidación de algunos deportes, de algunos géneros musicales y de algunos escritores y géneros literarios como "nacionales" (Archetti, 2003).

Las restantes categorías de hombres fotografiados individual o grupalmente ocupan ámbitos vinculados a los anteriores. La Argentina "productiva" es masculina, es decir, el trabajo extradoméstico constituye un universo de hombres. Podemos ver trabajadores en un frigorífico, en una mina, en un establecimiento industrial. Es sugestivo ver que hombres con y sin nombre, obreros y dirigentes gubernamentales, confluyen armónicamente en una doble página; de un lado, los obreros avanzan en la construcción del ferrocarril subterráneo, del otro, el presidente Victorino de la Plaza y otros asisten a su inauguración. La política es presentada también en este caso como territorio masculino. Si la dirección del Estado corresponde a los hombres "conocidos", las huelgas y ollas populares, y los meetings callejeros corresponden a los hombres "desconocidos"11. Los conflictos enfrentan (io entrelazan?) a hombres a un lado y a otro de la trinchera. Civiles, militares y policías en la Revolución de 1905; manifestantes y soldados en los sucesos de la Reforma Universitaria; obreros y represores durante la Semana Trágica; peones, estancieros y policías en las huelgas de la Patagonia de 1922-1923; en todos estos casos, la política es mostrada como cosa de hombres.

ILHA

volume 10 - número 2 
Sergio Caggiano

Junto con esta masculinización de la res publica, la "vía pública" es (sigue siendo) representada para esta época como lugar de los varones. Dos imágenes que se proponen plasmar un instante de la calle y de la vida urbana de Buenos Aires dan cuenta de ello. La primera muestra la calle Florida en el año 1901; la cámara se ha colocado en el medio de la calle, la cual se angosta en perspectiva hacia el centro del cuadro, por donde avanzan carruajes, encajonada entre fachadas de edificios y marquesinas, toldos y faroles de comercios. Podemos distinguir nítidamente alrededor de cincuenta personas en las veredas y la calzada. Todos son hombres. Algunos caminan, otros permanecen de pie, uno arrastra una bicicleta; algunos visten ropa de trabajo, otros, trajes distinguidos; una veintena de ellos se agrupa hacia la derecha, en un plano cercano. La segunda imagen es una toma similar a la anterior, en el cruce de Alsina y Defensa, hacia 1930. Enfoca una de las calles por las que marcha de frente un tranvía entre una docena de personas. Aquí también son todos hombres. Intercambian miradas y conversan, caminan o se detienen en la calle o en la acera, un canillita vocea el periódico, y a unos metros hay un carro de venta ambulante. Tanto en 1901 como en 1930, la vía pública se observa ocupada exclusivamente por hombres. Y hasta vale decir que estas estampas de la vida urbana de las primeras décadas del siglo XX se dejan "oír", además de ver. No es difícil imaginar los sonidos (masculinos) que llenan el aire de la ciudad: las voces de los transeúntes, los gritos del canillita o del vendedor ambulante, el silbato del tranvía o el de un agente policial, el ruido de los carros.

Las fotografías de mujeres dan cuenta de la apertura de un espacio en el campo de la "cultura", aunque ciertamente la limitación de la presencia femenina a una (1) escritora, una (1) escultora y dos (2) actrices de cine dibuja una apertura más que reducida. En la política, por otra parte, se vislumbra tenuemente alguna pequeña fisura en la exclusividad masculina. No obstante, las mujeres "conocidas" son mostradas en una dimensión más espectacular que política: Eva Perón se anuncia desde el fotograma de un film, la Infanta Isabel asiste a las celebraciones y pompas por el centenario de la Revolución de Mayo. Más significativa, aunque también reducida

ILHA

volume 10 - número 2 
La mirada (masculina) que insiste: imágenes y género en un álbum de fotos de la...

a una sola imagen, es la presencia de mujeres en lo que el redactor llama "comité femenino", que participa de una marcha tras la represión obrera de 1919 conocida como "Semana Trágica"12.

Por lo demás, el lugar común para las mujeres es otra vez el de la familia y la domesticidad. Las dos únicas imágenes que en este tomo muestran algunas mujeres juntas sin un hombre a la vista las muestran con niños. En una de ellas, mujeres atildadas acompañan a niños y niñas en su visita al jardín zoológico. En la otra, pueden verse algunas mujeres en la playa; una de ellas camina en primer plano de frente a la cámara, de la mano de un niño (posiblemente su hijo). En la misma dirección, van las escenas que reúnen a mujeres y hombres. Destaca por su tamaño de casi dos páginas una gran feria de productos frescos en la cual los vendedores (casi todos hombres) atienden a una gran cantidad de compradoras (casi todas mujeres), con niños y con bolsas en sus brazos. La imagen de este lugar de encuentro entre el trabajo "productivo" y el trabajo "de reproducción" parece repetir la extensión y el límite del trabajo doméstico fuera de la casa. Los otros "grupos mixtos" son indefectiblemente familias o parejas que pasean, bailan o disfrutan de un día al aire libre, siempre recordando reglas sociales más o menos explícitas, como en una postal de veraneo en que las mujeres (esposa e hija) caminan algunos centímetros detrás de los varones (esposo e hijo). Es sugerente "Familia en Córdoba (hacia 1915)", en la cual una familia se despliega delante de un automóvil. Agrupados/as, hacia la izquierda, la madre, la mucama y los/as niños/as. Las mujeres adultas miran a la cámara. El padre guarda una pequeña distancia del grupo y se recuesta sobre el auto, a la derecha de la toma. No mira al fotógrafo, y su cuerpo presenta una postura displicente, las manos en los bolsillos, una pierna cruzada con despreocupación por sobre la pierna restante en la cual sostiene su cuerpo. Su torso no da de frente a cámara, sino que se orienta un poco hacia el grupo. De manera sutil, el hombre nos presenta $s u$ auto, su familia, su esposa y su empleada.

Hay un elemento novedoso en la representación de las mujeres que Clarín reconstruye para este período. Se arraiga la relación biunívoca entre el mundo de la moda y el "mundo femenino", y

ILHA

volume 10 - número 2 
empieza a reiterarse la figura de "la mujer para ser mirada". Las fotos de mujeres y de matrimonios recorriendo las grandes tiendas de Buenos Aires o la de una vendedora exhibiendo medias de nailon son sólo las formas más simples en que se da la relación mujer-moda ${ }^{13}$. La misma fotografía mencionada de las mujeres (y el niño) en la playa "[...] muestra - según el epígrafe - la moda femenina playera que imperó en toda esa época". Una de las primeras escenas de este tomo, por su parte, deja ver parejas y familias de "buena posición" en el Hipódromo Argentino. El redactor indica bajo la imagen que, para ese entonces (1903), éste era "[...] un lugar 'para mirar y ser mirado"'. Considerando algunas imágenes posteriores, con mayor justeza creo que podría entenderse que lo que ésta anticipa es la constitución de lugares "para mirar (el hombre) y ser mirada (la mujer)". En esas décadas, se habrían dado, en el contexto de gestación de un mercado de la moda femenina, la conformación y confirmación de un régimen de miradas (masculinas) deseantes y cuerpos (femeninos) deseados en la calle (Mira, 2003; Vieira Botti, 2003). En síntesis, por lo que el archivo de Clarín enseña, la llegada de las mujeres a lugares sociales antes vedados fue limitada y condicionada. Esposas, madres y mujeres a la moda... Como la política, la calle abre para las mujeres espacios que buscan ser estructurados de acuerdo con una lógica y una mirada masculina.

No es necesario insistir en la descripción de imágenes que no agregarán nueva información. El tomo III (1945-1976) y, más aún, el tomo IV (1976-2005) presentan, respecto de los aspectos analizados hasta aquí, una continuidad inesperada por su magnitud y generalidad. Consecuentemente, hecha la mención de esta continuidad, me detendré tan sólo en los elementos nuevos que ellos aportan.

Los hombres individualizados con nombre y apellido en el tomo III son del campo político, sindical y militar, y también hay deportistas, cantantes y actores. Como puede verse en el cuadro de cantidades, un gran número de escenas reproduce a personajes de estos ámbitos en momentos en que son acompañados por sus partidarios o seguidos por el público. Todas las imágenes de hombres anónimos, solos o 
La mirada (masculina) que insiste: imágenes y género en un álbum de fotos de la...

en grupo, corresponden a los mismos ámbitos sociales; se exhiben principalmente confrontaciones o manifestaciones políticas callejeras o festejos deportivos.

Para las mujeres "conocidas" retratadas solas, se reserva una vez más una pequeña porción de "la cultura"; las vistas se reducen a una (1) artista plástica y a dos (2) "estrellas" de los medios de comunicación ${ }^{14}$. Las fotografías de mujeres "desconocidas", solas o en grupo, suman un total de tres (3). Destaca entre ellas la presencia de una obrera trabajando en su puesto al lado de una máquina, en una fábrica de bolsas. La imagen, de 1950, además de dar cuenta de una mayor actividad industrial, anuncia la mayor participación de las mujeres en el mercado de trabajo asalariado, que se ampliará algunos años más tarde, aunque el tema no deja de estar claramente subrepresentado con esta sola foto. La otra imagen importante es la única de este tomo en que se observa un grupo de mujeres. Son tres jóvenes que pasean en un predio de exposiciones. Caminan hacia la cámara, las tres muy arregladas, con el cabello, la ropa y el calzado cuidados, conversando entre sí en una actitud casual. El título es revelador: "Primeras minifaldas (1969)". De hecho, ése es el "objeto" de la fotografía: las minifaldas de dos de ellas y la pollera corta de la tercera, o mejor, las piernas de las tres o su elegancia, su adecuación a la moda o su sensualidad ocasional. En pocas palabras, una vez más estamos ante la imagen de aquello/as que está/n para ser mirado/as ${ }^{15}$.

Como en los tomos anteriores, no hay en éste imágenes del ámbito político que muestren a mujeres solas. Dado el período cubierto por este tomo, la pregunta por Eva Perón cae por su peso. Son tres las fotos en que aparece, las tres más o menos conocidas. Una de ellas es una toma contrapicada de Eva de frente saludando a sus adherentes - que se encuentran fuera de campo - con ambos brazos abiertos extendidos hacia arriba durante la proclamación de la fórmula "Perón-Evita" en agosto de 1951. Detrás de ella, es posible ver a dos hombres que la acompañan. En otra, vestida y peinada con gran elegancia, recorre los pasillos del Vaticano, hacia su encuentro con el papa Pío XII, rodeada de cardenales, edecanes, etc. La última lámina, que también es la más grande, representa una de sus últimas

ILHA

volume 10 - número 2 
apariciones en público, el 17 de octubre de 1951, pocos meses antes de su fallecimiento. Es la famosa imagen de Eva abrazando a Juan Domingo Perón en el balcón de la Casa Rosada, dando la espalda a los micrófonos y a la Plaza de Mayo, ocultando el rostro en el pecho de su esposo, mostrando a la cámara el prolijo rodete y la mano sobre la espalda de Perón, quien la sostiene a su vez con ambas manos. Unos veinte hombres en el balcón siguen la escena del matrimonio. Entre los muchos elementos que podrían ser analizados, me interesa destacar solamente que las imágenes elegidas de Eva la muestran siempre acompañada (escoltada o custodiada) por hombres. Estas imágenes, como se ha señalado para la iconografía de Eva en su conjunto, componen una gestualidad política que no niega los arquetipos de la belleza femenina, aunque los despoja de connotaciones eróticas, y que enmarca lo femenino en la figura de la esposa (y la madre simbólica de los pobres) y la institución matrimonial (Cortés Rocca y Kohan, 1998) ${ }^{16}$.

Por último, es muy relevante para este período cómo la presencia de las mujeres se impone en la representación de algunas modalidades de la participación o la militancia políticas. Si bien, exceptuando figuras como Eva Perón, las mujeres solas o en grupo no son asociadas a la política, en algunas de las imágenes de grupos de militantes o simpatizantes en actos públicos las mujeres están y se vuelven inevitablemente visibles. Se verifica, de esta forma, la presencia de "grupos mixtos" tanto en la emblemática foto "Las patas en la fuente" como en los festejos por el derrocamiento del gobierno de Perón, entre "Los presos de Trelew (1972)", etc. Sucede que, si algunas imágenes de la política han de tomarse en la calle, las mujeres, que están en la calle haciendo política, se meterán en esas imágenes.

¿Qué agrega el último de los tomos? En primer lugar, como es de esperar a esta altura de la exploración, "agrega" redundancia, es decir, pone de manifiesto la reiteración de las líneas centrales de análisis e interpretación propuestas hasta aquí. Es preciso resaltar esta continuidad y completa afinidad entre los cuatro tomos en cuanto al tratamiento del género en la representación de personas, situaciones y acciones. Se repite la concentración de hombres en la esfera de la 
La mirada (masculina) que insiste: imágenes y género en un álbum de fotos de la...

política (con alta presencia eclesiástica y militar) y en otros campos de actividad social (deportes, literatura, etc.), así como su presencia en las calles, lugares abiertos y escenarios urbanos. En otros términos, se repite el diseño de un espacio público masculino (masculinizado). Una pequeña "novedad", que no hace más que convalidar este argumento, es la aparición de imágenes de "la inseguridad ciudadana" (asaltos, tomas de rehenes) que muestran, otra vez, que la calle (en este caso, "la calle peligrosa y violenta") sigue siendo territorio de hombres.

Las fotografías de mujeres se reparten entre el arte y el espectáculo, con una levísima ampliación de áreas, ya que se incluyen dos reproducciones de una deportista. Lo más destacable del tomo IV es que un conjunto de imágenes prosigue y confirma lo señalado para el tomo III acerca de las mujeres que ganan visibilidad política a través de ganar la calle. En esta dirección, una fotografía representa a una monja (Marta Pelloni), quien, junto a los padres de una joven asesinada (María Soledad Morales), encabeza una marcha de la que participa un numeroso grupo de hombres y mujeres exigiendo justicia por el crimen. En la misma línea, la única imagen de un "grupo de mujeres" es una de las Madres de Plaza de Mayo, que recorren uno de los senderos de la Plaza, con la Casa de Gobierno como fondo. Otras fotos de las Madres corresponden a la categoría "grupos mixtos". Una es una amplia copia de una de las marchas alrededor de la Pirámide de Mayo, en la cual se observa un concurrido círculo que las apoya y acompaña. Otras vistas captan momentos en que las Madres resisten o evitan la represión policial a sus manifestaciones públicas. Otras fotografías, con un contenido más o menos directamente político, tienen asimismo a mujeres entre sus protagonistas. "Frente a frente (1989)", por ejemplo, intenta dar cuenta de los "saqueos" populares a supermercados que tuvieron lugar durante 1989 y principios de 1990 durante una crisis económica. Sobre los bordes laterales de la imagen, vemos las espaldas de dos policías (uno de ellos sin uniforme), algo borrosas, ya que el foco está puesto sobre el grupo de mujeres que unos metros delante de ellos los enfrentan ( $y$, de esta manera, enfrentan a la cámara $)^{17}$ y les gritan,

ILHA

volume 10 - número 2 
Sergio Caggiano

gesticulando mientras sostienen sus bolsas o cajas con alimentos. Las fotografías de los "saqueos" de 2001, de las protestas de "ahorristas" en 2002 contra los bancos y de la asistencia al acto de anuncio de la instalación de un Museo de la Memoria en la Escuela de Mecánica de la Armada también muestran a mujeres en las calles. Más allá de las diferencias, todas las fotos anteriores tienen en común el hecho de reponer la política como un espacio que es también de las mujeres. Como señalé respecto del tomo anterior, la presencia de las mujeres en las calles vuelve visible una forma de su participación política. No parece haber aquí una transformación en la modalidad con que el álbum de Clarín representa estos ámbitos, sino una transformación de los ámbitos mismos. La intervención femenina en manifestaciones, marchas, actos, etc., es inocultable, y cualquier registro visual de ellas registrará también la asistencia de las mujeres.

De todos modos, esto no modifica la tendencia general a reproducir una esfera pública masculinizada. Por un lado, por la mencionada concentración de hombres en la representación visual de la política y del espacio público en general. Las imágenes de mujeres constituyen verdaderamente un número ínfimo en relación con las de hombres. Por otro lado, por un aspecto que tienen en común estas fotos de mujeres en la política y que puede llevar a que nos preguntemos en qué medida algunas características (definitorias) de las mujeres representadas han hecho posible la aceptación social de su participación en la calle y en el espacio público. En el caso de una monja, ¿tiene relevancia el hecho de que, por ser tal, no sea "una mujer como cualquier otra", en tanto no cumple ni puede cumplir con la que es quizá la demanda social principal a las mujeres: la maternidad y la reproducción?, ¿podría ser que esto hiciera que no fueran "las mujeres" las representadas en la intervención de "la hermana"? Más importante aún, en los casos restantes, ¿no es precisamente la maternidad lo que las vuelve legítimas para la mirada hegemónica sobre el espacio público? Si se acepta esta sugerencia, la pregunta fundamental es en qué medida la visibilidad de la maternidad no opaca cualquier otro rasgo de esas mujeres como actoras de la política. De esta forma, en el caso de los "saqueos", tenemos madres

ILHA

volume 10 - número 2 
La mirada (masculina) que insiste: imágenes y género en un álbum de fotos de la...

desesperadas por llevar la comida a sus hogares; en el caso de las luchas por los derechos humanos, tenemos madres desesperadas por la pérdida de sus hijos. El aspecto común que comparten estas imágenes es la centralidad de la maternidad, y de esta forma lo que ha operado como una puerta de entrada al espacio de la política en la calle y en las instituciones puede acabar cerrando ese espacio o reduciéndolo a una función secundaria de la "función primera" y legítima de las mujeres: la maternidad. Las mujeres en la política serían madres en la política, luchando en su calidad de madres, movidas por intereses de madres y con la fuerza de las madres.

\section{Lugares en una historia contada desde la calle}

Cuantitativa y cualitativamente, esta historia en fotografías es masculina y patriarcal. Los hombres hacen la historia (no las mujeres). El ámbito de la "producción", de la cultura y del deporte nacionales y, sobre todo, de la política están en manos masculinas, en las de los grandes hombres, muchas veces; en las de los hombres anónimos, otras. Ésta es una historia mostrada en una medida importante a partir de los "acontecimientos políticos", y son los varones los que ocupan las calles y los palacios de gobierno. El espacio público es masculino también en otro sentido, pues la vía pública se ve habitada casi exclusivamente por hombres. El álbum parece recordarnos con insistencia que la calle es de los hombres y para ellos.

Las acciones de las mujeres son notoriamente subrepresentadas. El lugar "menor" que se les asigna en esta historia les es asignado en exclusividad. Es el espacio de la reproducción social y de la privacidad. Madre, esposa y trabajadora doméstica, a la mujer le toca la casa (y la casa le toca sólo a la mujer). Las imágenes revalidan la división sexual del trabajo y su valoración desigual. La casa no es el lugar desde donde se cuenta esta historia. Para una crítica de la forma que esta reclusión tiene en el capitalismo, es imprescindible tener presente tanto el confinamiento de las mujeres al trabajo doméstico como, igualmente, la desvalorización de éste. Como han mostrado autoras feministas, es sustancial que el trabajo doméstico sea en nuestras

ILHA

volume 10 - número 2 
sociedades a la vez "inferior" e "invisible", es decir, que el valor social de las funciones vaya atado al valor reconocido a aquellos (aquellas) que las desempeñan ${ }^{18}$. Esta línea de interpretación es fundamental para comprender el trabajo de selección y colección de este álbum.

Otras imágenes dan cuenta de cierta ambigüedad o ambivalencia, en la medida en que parecen hacerse eco de movimientos que podrían abrir grietas en esta tendencia general, pero que a fin de cuentas no pueden romperla o superarla. La vinculación de las mujeres al mundo del espectáculo y de la moda no deja de recordarnos que el acceso a estos ámbitos es producto de la "agencia" y el papel activo de estas mujeres. Sin embargo, su puesta en imágenes reactiva el viejo motivo de la mujer mostrada para ser vista, es decir, de la mujer como espectáculo ella misma: cuerpo deseado por/para la mirada masculina. En otras vistas, las mujeres imponen su imagen en espacios institucionales y en la calle, y estas apariciones reflejan el avance de las mujeres en la política y en el espacio público, pero la visibilización de este fenómeno parece limitar los desafíos que éste conlleva al codificarlo y enmarcarlo en otro clásico leit motiv: el de la "maternidad politizada".

En conclusión, una aparición de las mujeres reducida y confinada a "rincones" de la vida social se mantiene como disposición general a pesar de ciertas variaciones. La historia argentina en fotografías de Clarín imagina para las mujeres un espacio regulado, con zonas vedadas y zonas exclusivas. La subrepresentación en algunas áreas se complementa con la ligazón fija a un tipo de actividades que les corresponderían por "naturaleza" y con la desvalorización de esas actividades.

El juego de visibilizaciones y ocultamientos es complejo; el lugar de Clarín como enunciador, también. El contexto económico, político e intelectual de la toma fotográfica, así como el propósito con que fue hecha y la relación entre el responsable de ella y su "objeto" (Scherer, 1996) estructuran en gran medida cada imagen. Podrían rastrearse estos elementos en el enfoque, el encuadre, el juego de miradas de las fotografías analizadas, o en el hecho mismo de que los hombres ocupen las calles o los sitiales del poder político.

ILHA

volume 10 - número 2 
La mirada (masculina) que insiste: imágenes y género en un álbum de fotos de la...

Desde esta perspectiva, Clarín apenas reflejaría y reiteraría los criterios de lo fotografiable y de lo fotografiado. Las relaciones de poder que están o estaban en "la realidad" serían así trasladadas a la imagen en el álbum. Podría pensarse entonces que Clarín simplemente deja ver lo que una sociedad (patriarcal) "es", limitándose a mostrar "lo que hay". Si éste fuera el caso, sería atinado recordar la advertencia de Adorno y Horkheimer acerca del funcionamiento de la ideología en la "industria cultural" como insistente repetición de la realidad vigente como la única realidad posible ${ }^{19}$.

Pero es preciso ir más allá y enfatizar que no es éste el caso: que mostrar (seleccionar y confeccionar una muestra) nunca es simplemente "mostrar lo que hay". Esto queda claro desde el momento en que aquellas relaciones de poder no se nombran, presentan o indican como tales. Por otra parte, son muchos los mecanismos que vuelven ostensible el carácter de intervención que tiene la edición y el armado del repertorio (basta recordar el efecto de anclaje de los epígrafes). Es claro que no se refleja "la realidad" (ni puede hacérselo en un sentido positivista), sino que se postula una forma de verla, una perspectiva. La perspectiva en este caso es la de los hombres que ocupan calles, plazas y balcones para tomar la política en "sus" manos. Lo que vale la pena recordar es que elegir una perspectiva (masculina) es re-producirla, es decir, participar activamente en su normalización y legitimación ideológica.

\section{Referencias}

ADORNO, Theodor y HORKHEIMER, Max. Ideología, en La sociedad: lecciones de Sociología. Buenos Aires: Proteo, 1969.

ANDERSON, Benedict. Comunidades imaginadas. México: Fondo de Cultura Económica, 1993.

ARCHETTI, Eduardo. Masculinidades. Buenos Aires: Antropofagia, 2003.

BARTHES, Roland. El mensaje fotográfico, en Lo obvio y lo obtuso: imágenes, gestos, voces. Barcelona: Paidós, 1992.

BENHABIB, Seyla. The claims of culture: equality and diversity in the global era. Princeton: Princeton University Press, 2002.

ILHA

volume 10 - número 2 
Sergio Caggiano

BERGER, John. Ways of seeing. Londres: British Broadcasting Corporation and Penguin Books, 1972.

BOURDIEU, Pierre (comp.). La fotografía: un arte intermedio. México: Nueva Imagen, 1989.

CAGGIANO, Sergio. En prensa. La mirada racializada: revisión de un álbum de fotos de la historia argentina, en Cadernos de Antropologia e Imagem, $\mathrm{n}^{\circ} 24$.

CORTÉS ROCCA, Paola y KOHAN, Martín. Imágenes de vida, relatos de muerte. Rosario: Beatriz Viterbo, 1998.

DAMATTA, Roberto. A casa e a rua. Rio de Janeiro: Rocco, 1997.

DAMATTA, Roberto. Carnavales, malandros y héroes. México: Fondo de Cultura Económica, 2002.

EDWARDS, Elizabeth. Antropologia e fotografia, en Cadernos de Antropologia e Imagem, núm. 2, UERJ, 1996.

FOUCAULT, Michel. Vigilar y castigar. Buenos Aires: Siglo XXI, 1989.

FRASER, Nancy. Iustitia Interrupta: reflexiones críticas desde la posición "postsocialista". Bogotá: Universidad de los Andes/Siglo del Hombre Editores, 1997.

HABERMAS, Jurgen. Historia y crítica de la opinión pública. Barcelona: Gustavo Pili, 1994.

MIRA, Maria Celeste. O masculino e o feminino nas narrativas da cultura de massas ou o deslocamento do olhar, en Cadernos Pagu, no 21, p. 13-38, 2003.

POOLE, Deborah. Visión, raza y modernidad: una economía visual del mundo andino de imágenes. Lima: Sur Casa de Estudios del Socialismo y Consejería de Proyectos, 2000.

SANTAELLA, Lucia y NÖTH, Winfried. 1996. Imagen: Comunicación, semiótica y medios. Mimeo.

SCHERER, Joanna. Documentário fotográfico: fotografias como dado primário na pesquisa antropológica, en Cadernos de Antropologia e Imagem, núm. 3, UERJ, 1996.

SMITH, Shawn Michelle. American Archives: gender, race, and class in visual culture. New Jersey: Princeton University Press, 1999.

STOLCKE, Verena. Los trabajos de las mujeres, en LEÓN, Magdalena (ed.), Debate sobre la mujer en América Latina y el Caribe, Vol. III. Sociedad, subordinación y feminismo. Bogotá: ACEP, 1982.

VIEIRA BOTTI, Mariana Meloni. Fotografia e fetiche: um olhar sobre a imagem da mulher, en Cadernos Pagu, no 21, p. 103-131, 2003.

ILHA

volume 10 - número 2 
La mirada (masculina) que insiste: imágenes y género en un álbum de fotos de la...

\section{Notas}

1 Clarín es el periódico más influyente de Argentina. Editado en Buenos Aires, es por mucho el de mayor tirada y más amplia distribución en el país, además de ser la referencia privilegiada tanto por otros medios como por políticos y por dirigentes de diversos sectores e instituciones en la "definición de agenda". En sus más de sesenta años de existencia, el diario llegó a convertirse en el primer medio del holding multimedia más grande del país y uno de los más grandes de América Latina y, al menos de acuerdo con estas características, se podría aceptar que es, como su slogan pretende, "el gran diario argentino". Además de su gran "llegada", razón de peso per se, suma interés el hecho de que para (y por) lograr esa gran "llegada", Clarín se propone (se presenta, se escribe, se ilustra, se diseña, etc.) como una mirada "promedio", algo así como la mirada media de la mítica clase media argentina, con una notable cantidad y variedad de suplementos y secciones especializadas que buscan completar una estrategia de mercado del tipo "toma todo".

2 Con mayor precisión, el tomo I (128 imágenes) está compuesto por los capítulos "De los orígenes a la organización nacional" y "La Generación del 80"; el tomo II ( 120 imágenes), por los capítulos "Del siglo XIX al siglo XX", "El comienzo de la democracia", "La era de los golpes"; el tomo III ( 112 imágenes), por "El peronismo en el poder", "Gobiernos militares y democracias débiles" y "El tercer peronismo"; y el tomo IV ( 127 imágenes), por "La dictadura más violenta" y "La vuelta de la democracia". Cada capítulo es introducido mediante breves artículos escritos por académicos especialistas en el período en cuestión. Estos artículos no forman parte del material que analizo.

3 La fotografía en la Historia Argentina, Buenos Aires, Clarín-AGEA, 2005, tomo I, p. 3.

4 Me detengo sobre esta dimensión en particular en otro artículo (Caggiano, en prensa).

5 El término "grupo" no tiene aquí ningún alcance sociológico. Es utilizado en su acepción de agrupamiento, conjunto o reunión.

6 Sin dudas, la clasificación tiene zonas de ambigüedad y de difícil definición. Por poner sólo un ejemplo: una fotografía de Eva Perón en el balcón de la Casa de Gobierno junto a Juan Domingo Perón y otros dirigentes políticos ¿sería una imagen de un "grupo mixto"? A mi juicio, es claro que no. En la medida en que la primera línea del epígrafe indica "[...] (f)ue una de las últimas apariciones en público de Evita [...]" (p. 320) y de la centralidad de su figura en la toma, ella es contada dentro de la categoría "Mujeres 'con nombre' acompañadas". Casos similares a éste han sido resueltos con criterios semejantes. Por otro lado, a partir del tomo III hay fotos de personas conocidas de ambos sexos juntas. Su número no es significativo y no vuelven necesario crear una categoría nueva.

7 En este conjunto de escenas, como en otras más adelante, se hacen patentes las diferencias de clase social (y "raciales") atravesando el género. Las mujeres que son mostradas trabajando son amas de casa pobres o son empleadas. Algunas de ellas son negras. Las mujeres de familias acomodadas son retratadas precisamente como tales: mujeres de familia, en algunos casos "trabajando como esposas". (Por supuesto, como quedará claro a medida que ofrezca más ejemplos, la desigualdad de clase determina también algunas diferencias en la representación de los hombres).

8 Sobre este punto, ver Habermas (1994) y, para su crítica, Fraser (1997) y Benhabib (2002). A propósito de la división entre espacio público y privado y su relación con la división sexual del trabajo, Fraser ha señalado el conjunto de "[...] oposiciones jerárquicas y dicotomías fundamentales para la cultura capitalista contemporánea:

ILHA

volume 10 - número 2 
masculino-femenino, público-privado, trabajo-cuidado, éxito-amor, individuocomunidad, economía-familia y competitivo-altruista" (Fraser, op. cit.,p. 200; corresponde al cap. 5, "Una genealogía de la 'dependencia'”, escrito en colaboración con Linda Gordon).

9 La distinción está inspirada en la que propusiera DaMatta entre "casa" y "rua" y procura para estos términos la densidad que el autor les da, en el sentido de que "[...] no designan simplemente espacios geográficos o cosas físicas conmensurables, sino por sobre todo entidades morales, esferas de acción social, jurisdicciones éticas dotadas de positividad, dominios culturales institucionalizados y, por causa de ello, capaces de despertar emociones, relaciones, leyes, oraciones, músicas, imágenes estéticamente encuadradas e inspiradas" (DaMatta, 1997, p. 15, mi traducción; ver también DaMatta, 2002, cap. II), si bien no recupero aquí la totalidad de las características con que estos conceptos buscan, en su contexto original, dar cuenta de cierta especificidad de la sociedad brasilera.

${ }^{10}$ Los retratos de hombres también recurrían a mesas y sillas, en gran medida en respuesta a las condiciones materiales que las técnicas fotográficas de esa época imponían. Los muebles permitían sostener el cuerpo el tiempo necesario para la toma, completando la función de los "sostenedores de nuca" que es posible detectar en varias de estas imágenes. Pero más allá del aspecto común, el mueble que acompaña a los hombres suele ser el escritorio y no la mesa con mantel.

11 También el ámbito de las elecciones es masculino, como lo muestran fotos de la preparación de urnas para votar y de mesas de votación en las primeras décadas del siglo XX. Las mujeres pudieron votar en elecciones nacionales en Argentina por primera vez en 1951

12 La foto pertenece al Archivo General de la Nación. La inscripción que la copia existente en el Archivo tiene es "Semana Trágica. Obreros que acompañaron el cortejo fúnebre y un grupo de mujeres del 'Comité Feminista'. Enero 1919". La transformación de "feminista" en "femenino" en la publicación de Clarín no parece un dato menor.

13 Otra lectura posible de esta última imagen nos hace ver que se trata de una mujer trabajando fuera del ámbito doméstico.

${ }^{14}$ Otras figuras de la industria cultural (especialmente televisión y cine) son presentadas entre las mujeres conocidas acompañadas. Dado que en todos estos casos se trata de fotogramas que extractan instantes de la actuación, analizar en detalle estas apariciones implicaría abordar un doble juego de representaciones, el de la fotografía y el del fotograma (es decir, la imagen de la actriz " $\mathrm{x}$ " en un instante de un film es la imagen de " $\mathrm{x}$ " en tanto que actriz, pero también es la imagen de su personaje " $y$ " en ese film, y el personaje ya no es la actriz, ni representa lo que la actriz en tanto que tal...). No obstante no detenernos en este punto, es interesante mencionar qué clase de personajes, acciones o ámbitos se presentan en los fotogramas: una de las mujeres protagoniza una madre (en la imagen, sentada a una mesa servida); una comediante friega los pisos en el papel de una empleada doméstica, con su pañuelo en la cabeza y su delantal; una conductora de televisión, en el set televisivo arreglado como el living o el vestíbulo de una casa, toma una taza de café.

15 Recordando las advertencias metodológicas hechas en la nota anterior, vale señalar aquí otros dos fotogramas de mujeres "conocidas" recuperados del cine: en uno, se ve la espalda descubierta y el perfil del rostro de Olga Zubarry, la actriz que protagonizó el primer desnudo del cine argentino, con un hombre que la observa a su derecha y

ILHA

volume 10 - número 2 
La mirada (masculina) que insiste: imágenes y género en un álbum de fotos de la...

apenas detrás de ella; en el otro, se ve a Isabel Sarli, uno de los "símbolos sexuales" del cine nacional, con una bikini con estampado de leopardo, exhibiendo su cuerpo a la mirada del hombre a su lado (y a la cámara).

${ }^{16}$ La iconografía de Eva Perón seguramente merece un estudio particular. El citado trabajo de Cortés Rocca y Kohan presenta algunos aportes interesantes. Respecto a mujeres en la política, vale aclarar también que en este mismo tomo es posible hallar algunas fotos de María Estela Martínez de Perón en compañía de su esposo o de generales de las Fuerzas Armadas.

17 La cámara, dicho sea de paso, ocupa un lugar entre la policía. También vale apuntar que se trata de un grupo formado exclusivamente por mujeres pero el epígrafe indica "Un grupo de vecinos...".

${ }^{18}$ Verena Stolcke, por ejemplo, sostiene “[...] que en tanto que la opresión de clase y la división social del trabajo tienen su origen en el acceso desigual a los medios de producción, es la reproducción social, o sea, la perpetuación de las relaciones y la dominación de clase - mediada directamente por las instituciones del matrimonio, la familia y la herencia - lo que requiere (y en consecuencia determina) tanto la dedicación primordial de la mujer al trabajo doméstico cuanto la subvaloración de sus funciones" (Stolcke, 1982, p. 15).

19 En palabras de los autores, la ideología de la cultura de masas opera "[...] como duplicación y justificación ultravalidadora de la situación ya existente", lo cual destruye toda perspectiva de crítica, y se limita a poner bajo los ojos de hombres y mujeres, "[...] lo que ya constituye la condición de su existencia, a la vez que proclama ese existente como su propia norma; de ese modo, los confirma y consolida [...]" (Adorno y Horkheimer, 1969, p. 204).

Recebido em: 17/06/2008

Aceite em: 09/08/2008

ILHA

volume 10 - número 2 